\title{
Acidic Dissociation of Diprotonated Piperazine in Methanol-Water Solvents From 10 to $40{ }^{\circ} \mathrm{C}$
}

\author{
Maya Paabo and Roger G. Bates* \\ Institute for Materials Research, National Bureau of Standards, Washington, D.C. 20234
}

(May 6, 1970)

\begin{abstract}
The first dissociation constant of piperazinium ion has been determined by the emf method in five methanol-water solvents $(10$ to $70 \mathrm{wt} \% \mathrm{MeOH})$ at $25{ }^{\circ} \mathrm{C}$ and in three solvents $(10,20$, and 50 wt $\% \mathrm{MeOH}$ ) from 10 to $40{ }^{\circ} \mathrm{C}$. From the variation of the dissociation constant with temperature, the changes of enthalpy, entropy, and heat capacity were derived and compared with similar data for piperazinium ion in water. The variation of $p K, \Delta S^{\circ}$, and $\Delta C_{p}^{\circ}$ have been used to interpret the effect of the double positive charge on the solute-solvent interactions as compared to the effect exhibited by a single positive or a negative charge.
\end{abstract}

Key words: Dissociation constant; ionization constant; methanol; mixed solvents; piperzaine; pK; thermodynamics.

\section{Introduction}

The piperazinium ion dissociates in two stages:

$$
\begin{gathered}
\mathrm{PzH}_{2}^{++}+\mathrm{H}_{2} \mathrm{O} \leftrightarrows \mathrm{H}_{3} \mathrm{O}^{+}+\mathrm{PzH}^{+}, \quad \mathrm{K}_{1} \\
\mathrm{PzH}^{+}+\mathrm{H}_{2} \mathrm{O} \leftrightarrows \mathrm{H}_{3} \mathrm{O}^{+}+\mathrm{Pz}, \quad \mathrm{K}_{2}
\end{gathered}
$$

where $\mathrm{P}_{\mathrm{z}}$ represents the neutral base piperazine,

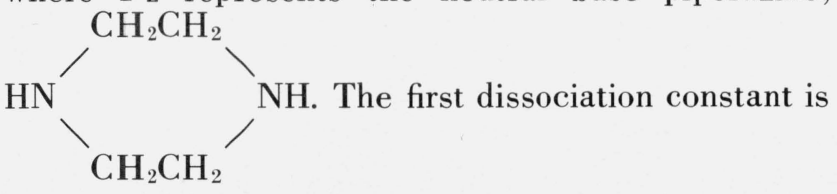

about 25,000 times as large as the second, so the two equilibria can conveniently be studied separately.

In elucidating the role of ionic charge in ion-solvent interactions, the influence of changing solvent composition on an equilibrium such as the first stage in the dissociation of diprotonated piperazinium ion is of unusual interest. Although considerable attention has been devoted to the nature of solvent effects on the dissociation and related thermodynamic behavior of neutral and singly charged acids, it appears that no similar investigation of the dissociation of a doubly charged cation acid has been made. It is the purpose of this paper to report the results of a study of the first dissociation of piperazinium ion in five methanol-water solvents containing $10,20,33.4,50$, and $70 \mathrm{wt}$ percent methanol.

*Present address: Department of Chemistry, University of Florida, Gainsville, Florida 32601 .

\section{Method}

The $p_{s} K_{1}$ of piperazinium ion in methanol-water mixtures was determined by measuring the emf of the cell

$\mathrm{Pt} ; \mathrm{H}_{2}(\mathrm{~g}, \mathrm{l} \mathrm{atm}), \mathrm{Pz} \cdot 2 \mathrm{HCl}(m)$,

$\mathrm{Pz} \cdot \mathrm{HCl}(m)$ in $X$ wt $\%$ methanol, $\mathrm{AgCl} ; \mathrm{Ag}$

where $m$ is molality and $X$ is $10,20,33.4,50$, or 70 wt percent. The measurements in 33.4 and $70 \mathrm{wt}$ percent methanol were made at $25{ }^{\circ} \mathrm{C}$ and those in 10,20 , and $50 \mathrm{wt}$ percent methanol from 10 to $40^{\circ} \mathrm{C}$.

The $p_{s} K_{1}$ was calculated by the equation

$$
\begin{aligned}
p_{s} K_{1}=\frac{\left(E-{ }_{s} E^{\circ}\right) F}{R T \ln 10}+\log m_{\mathrm{Cl}}- & +\log \frac{m_{\mathrm{PzH}_{2}^{++}}}{m_{\mathrm{PzH}^{+}}} \\
& +\log { }_{s}\left(\frac{\gamma_{\mathrm{PzH}_{2}^{++}} \cdot \gamma_{\mathrm{Cl}^{-}}}{\gamma_{\mathrm{PzH}^{+}}}\right)
\end{aligned}
$$

where ${ }_{s} E^{\circ}$ is the standard potential of the silver-silver chloride electrode in methanol-water mixtures $[1-4] .{ }^{1}$

The activity coefficients of each ionic species $i$ was estimated with the aid of the Debye-Hückel equation

$$
-\log _{s} \gamma_{i}=\frac{A \sqrt{I} \sqrt{d_{0}}}{1+B \stackrel{\circ}{a} \sqrt{I} \sqrt{d_{0}}}
$$

\footnotetext{
${ }^{1}$ Figures in brackets indicate the literature references at the end of this paper.
} 
where $A$ and $B$ are the constants of the Debye-Hückel theory, dependent only on the temperature and dielectric constant of the solvent, $d_{0}$ is the density of the solvent, $I$ is the total ionic strength, and $a$ is the ion-size parameter. The values of $A \sqrt{d_{0}}$ and $B \sqrt{d_{0}}$ for the solvent mixtures have been given elsewhere $[3,5,6]$.

A small correction for the ionization of the $\mathrm{PzH}_{2}^{++}$ ion was made by estimating the molality of hydrogen ion formed with the aid of the approximation

$-\log m_{\mathrm{H}}=p_{s}\left(a_{\mathrm{H}} \gamma_{\mathrm{Cl}}\right)+\log _{s}\left(\gamma_{\mathrm{H}} \gamma_{\mathrm{Cl}}\right)=p_{s}\left(a_{\mathrm{H}} \gamma_{\mathrm{Cl}}\right)$

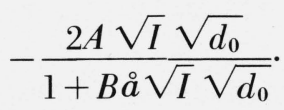

The acidity function $p_{s}\left(a_{\mathrm{H}} \gamma_{\mathrm{Cl}}\right)$ was derived from the experimental data by the equation

$$
p_{s}\left(a_{\mathrm{H}} \gamma_{\mathrm{Cl}}\right)=\frac{\left(E-{ }_{s} E^{\circ}\right) F}{R T \ln 10}+\log m_{\mathrm{Cl}^{-}} .
$$

The "approximate" dissociation constant $p_{s} K_{1}^{\prime}$ was then defined as follows:

$$
\begin{aligned}
p_{s} K_{1}^{\prime} \equiv \frac{\left(E-{ }_{s} E^{\circ}\right) F}{R T \ln 10} & +\log m_{\mathrm{Cl}^{-}}+\log \frac{m-m_{\mathrm{H}^{+}}}{m+m_{\mathrm{H}^{+}}} \\
- & \frac{4 A \sqrt{I} \sqrt{d_{0}}}{1+B \stackrel{\circ}{ } \sqrt{I} \sqrt{d_{0}}}=p_{s} K_{1}-\beta I
\end{aligned}
$$

where $\beta$ is the slope parameter. The $p_{s} K_{1}^{\prime}$ varies linearly with $I$ when the proper value of $a$ is chosen; its value at infinite dilution is $p_{s} K_{1}$. The method of least squares with the OMNITAB computer program was used to calculate the values of $p_{s} K_{1}, \beta$, and $\stackrel{a}{a}$. The "true" values of $p_{s} K_{1}, \beta$, and $a$ were assumed to be those which gave the smallest standard deviation of regression.

\section{Experimental Procedure}

The general experimental procedures closely fol-

\begin{tabular}{|c|c|c|c|c|c|c|c|}
\hline$m$ & $10^{\circ}$ & $15^{\circ}$ & $20^{\circ}$ & $25^{\circ}$ & $30^{\circ}$ & $35^{\circ}$ & $40^{\circ}$ \\
\hline \multicolumn{8}{|c|}{$10 \mathrm{Wt} \%$ Methanol } \\
\hline $\begin{array}{c}0.002689 \\
.005166 \\
.007367 \\
.009903 \\
.01218 \\
.01471 \\
.01746 \\
.01981 \\
.02226 \\
.02463 \\
.03761 \\
.04970\end{array}$ & $\begin{array}{r}0.66092 \\
.64872 \\
.64245 \\
.63747 \\
.63415 \\
.63112 \\
.62851 \\
.62653 \\
.62482 \\
.62332 \\
.61742 \\
.61364\end{array}$ & $\begin{array}{r}0.66031 \\
.64792 \\
.64155 \\
.63652 \\
.63314 \\
.63006 \\
.62741 \\
.62532 \\
.62366 \\
.62215 \\
.61615 \\
.61230\end{array}$ & $\begin{array}{r}0.65949 \\
.64689 \\
.64043 \\
.63532 \\
.63189 \\
.62877 \\
.62608 \\
.62401 \\
.62227 \\
.62073 \\
.61465 \\
.61073\end{array}$ & $\begin{array}{r}0.65844 \\
.64563 \\
.63908 \\
.63389 \\
.63041 \\
.62725 \\
.62451 \\
.62244 \\
.62067 \\
.61910 \\
.61293 \\
.60897\end{array}$ & $\begin{array}{r}0.65713 \\
.64417 \\
.63751 \\
.63226 \\
.62873 \\
.62553 \\
.62277 \\
.62062 \\
.61885 \\
.61728 \\
.61101 \\
.60700\end{array}$ & $\begin{array}{r}0.65564 \\
.64248 \\
.63573 \\
.63041 \\
.62683 \\
.62360 \\
.62078 \\
.61853 \\
.61682 \\
.61524 \\
.60889 \\
.60484\end{array}$ & $\begin{array}{r}0.65397 \\
.64058 \\
.63375 \\
.62835 \\
.62473 \\
.62145 \\
.61862 \\
.61644 \\
.61461 \\
.61299 \\
.60658 \\
.60247\end{array}$ \\
\hline \multicolumn{8}{|c|}{$20 \mathrm{Wt} \%$ Methanol } \\
\hline $\begin{array}{c}0.003242 \\
.006150 \\
.008753 \\
.01204 \\
.01513 \\
.01781 \\
.02146 \\
.02382 \\
.02714 \\
.03270 \\
.04548 \\
.04863\end{array}$ & $\begin{array}{r}0.64453 \\
.63318 \\
.62734 \\
.62226 \\
.61884 \\
.61651 \\
.61382 \\
.61242 \\
.61062 \\
.60812 \\
.60395 \\
.60308\end{array}$ & $\begin{array}{r}0.64354 \\
.63203 \\
.62610 \\
.62094 \\
.61748 \\
.61511 \\
.61238 \\
.61096 \\
.60914 \\
.60658 \\
.60237 \\
.60147\end{array}$ & $\begin{array}{r}0.64234 \\
.63066 \\
.62465 \\
.61941 \\
.61591 \\
.61350 \\
.61073 \\
.60930 \\
.60745 \\
.60486 \\
.60057 \\
.59967\end{array}$ & $\begin{array}{r}0.64090 \\
.62906 \\
.62295 \\
.61766 \\
.61410 \\
.61167 \\
.60886 \\
.60741 \\
.60553 \\
.60292 \\
.59855 \\
.59767\end{array}$ & $\begin{array}{r}0.63928 \\
.62727 \\
.62110 \\
.61573 \\
.61211 \\
.60967 \\
.60682 \\
.60536 \\
.60345 \\
.60082 \\
.59641 \\
.59550\end{array}$ & $\begin{array}{r}0.63741 \\
.62528 \\
.61904 \\
.61358 \\
.60993 \\
.60745 \\
.60457 \\
.60309 \\
.60117 \\
.59849 \\
.59405 \\
.59312\end{array}$ & $\begin{array}{r}0.63545 \\
.62305 \\
.61675 \\
.61122 \\
.60752 \\
.60502 \\
.60210 \\
.60061 \\
.59867 \\
.59597 \\
.59148 \\
.59055\end{array}$ \\
\hline \multicolumn{8}{|c|}{$50 \mathrm{Wt} \%$ Methanol } \\
\hline $\begin{array}{c}0.002483 \\
.005169 \\
.007478 \\
.009872 \\
.01198 \\
.01501 \\
.01728 \\
.01996 \\
.02213 \\
.02501 \\
.04988\end{array}$ & $\begin{array}{r}0.61288 \\
.60115 \\
.59609 \\
.59211 \\
.58983 \\
.58688 \\
.58540 \\
.58360 \\
.58262 \\
.58113 \\
.57446\end{array}$ & $\begin{array}{r}0.61033 \\
.59846 \\
.59336 \\
.58933 \\
.58699 \\
.58407 \\
.58258 \\
.58076 \\
.57980 \\
.57826 \\
.57156\end{array}$ & $\begin{array}{r}0.60773 \\
.59568 \\
.59051 \\
.58647 \\
.58407 \\
.58115 \\
.57966 \\
.57781 \\
.57685 \\
.57532 \\
.56857\end{array}$ & $\begin{array}{r}0.60490 \\
.59271 \\
.58747 \\
.58339 \\
.58100 \\
.57803 \\
.57653 \\
.57469 \\
.57371 \\
.57216 \\
.56541\end{array}$ & $\begin{array}{r}0.60189 \\
.58953 \\
.58425 \\
.58015 \\
.57780 \\
.57469 \\
.57325 \\
.57142 \\
.57041 \\
.56888 \\
.56210\end{array}$ & $\begin{array}{r}0.59882 \\
.58618 \\
.58090 \\
.57673 \\
.57439 \\
.57133 \\
.56982 \\
.56795 \\
.56698 \\
.56542 \\
.55864\end{array}$ & $\begin{array}{r}0.59559 \\
.58280 \\
.57746 \\
.57326 \\
.57088 \\
.56784 \\
.56630 \\
.56445 \\
.56344 \\
.56190 \\
.55511\end{array}$ \\
\hline
\end{tabular}
lowed those used previously in methanol-water

TABle 1. Electromotive force of the cell: $\mathrm{Pt} ; \mathrm{H}_{2}(\mathrm{~g}, 1 \mathrm{~atm})$, Piperazine $\cdot 2 \mathrm{HCl}(\mathrm{m})$, Piperazine $\cdot \mathrm{HCl}(\mathrm{m}), \mathrm{AgCl}$; $\mathrm{Ag}$ in water-methanol mixtures from 10 to $40^{\circ} \mathrm{C}$ (in volts) 
system [3] and applied to a determination of the dissociation constants of piperazinium ion in water [7]. The cells used were of the improved type described elsewhere [8].

A stock solution containing equal moles of piperazine mono- and dihydrochloride was prepared by dissolving the required weight of free piperazine in standard aqueous hydrochloric acid. Weight dilutions with additional water and methanol were made to achieve the desired molality and solvent composition.

Methanol (spectro grade) was used as obtained commercially without further purification. Hydrochloric acid for the preparation of solutions was distilled twice and standardized by gravimetric determination of chloride. The piperazine was a portion of the same material used for the study in water [7].

\section{Results}

The emf data, corrected to $1 \mathrm{~atm}$ hydrogen pressure, are summarized in tables 1 and 2 . The values of $p_{s} K_{1}$ and $\stackrel{a}{a}$ derived from the experimental data are listed in table 3 . The estimated uncertainties in $p_{s} K_{1}$ are given in the last column of table 3 . They represent two standard deviation limits.

The experimental $p_{s} K_{1}$ values were fitted to the Harned-Robinson equation [9], where $T$ is the thermodynamic temperature,

$$
p K=A / T+B+C T
$$

by the method of least squares using the OMNITAB computer program. The constants $A, B$, and $C$ are given in table 4 . The residual standard deviation of the fit to the Harned-Robinson equation was less than 0.001 in all three methanol-water mixtures.

\section{Thermodynamic Functions}

The standard thermodynamic quantities for the acidic dissociation of piperazinium ion in three methanol-water mixtures were calculated by the usual thermodynamic formulas from the constants of eq (6) given in table 4 . The values for 10,25 , and 40 ${ }^{\circ} \mathrm{C}$ are listed in table 5. The estimated uncertainties in these values at $25{ }^{\circ} \mathrm{C}$ are given in parentheses. They again represent two standard deviation limits as obtained by variance analysis.

\section{Discussion}

The effect of changing solvent composition on the acidic dissociation constant of diprotonated piperazinium ion and the associated thermodynamic constants for the dissociation process are summarized in table 6 . As is the case for singly charged cation acids, enrichment of the solvent with methanol increases the degree of dissociation. Unlike most of the singly charged cation acids, however, the $p K$ of diprotonated piperazinium ion appears not to have reached a minimum at a solvent composition of 70 wt percent meth- anol. With the decrease in $p K$ there is a small regular increase in the enthalpy of dissociation. Much more striking, however, are the changes in the entropy and heat capacity of dissociation when the percentage of methanol in the solvent is increased. The entropy change becomes rapidly more positive, while the

TABLE 2. Electromotive force of the cell: $\mathrm{Pt} ; \mathrm{H}_{2}(g, 1$ atm), Piperazine $\cdot 2 \mathrm{HCl}(m)$, Piperazine $\cdot \mathrm{HCl}(m)$, $\mathrm{AgCl} ; \mathrm{Ag}$ in water-methanol mixtures at $25{ }^{\circ} \mathrm{C}$ (in volts)

\begin{tabular}{c|c|c|c}
\hline \multicolumn{4}{c}{ Wt \% Methanol } \\
\multicolumn{3}{c}{33.4} & \multicolumn{2}{c}{70} \\
\hline & & & \\
& & $m$ & $E$ \\
\hline & & & \\
0.002375 & 0.62944 & 0.002457 & 0.57070 \\
.004876 & .61584 & .005206 & .56024 \\
.007578 & .60842 & .009058 & .55410 \\
.009933 & .60416 & .01009 & .55289 \\
.01261 & .60060 & .01241 & .55097 \\
.01495 & .59817 & .01456 & .54940 \\
.01762 & .59588 & .01844 & .54744 \\
.02032 & .59396 & .01976 & .54682 \\
.02253 & .59255 & .02388 & .54534 \\
.02516 & .59114 & .02458 & .54508 \\
.03744 & .58620 & .03653 & .54222 \\
.05018 & .58279 & & \\
\hline
\end{tabular}

TABLE 3. The first dissociation constant of piperazinium ion in five water-methanol solvent mixtures from 10 to $40{ }^{\circ} \mathrm{C}$

\begin{tabular}{|c|c|c|c|c|}
\hline Wt \% Methanol & $t$ & $p_{s} K_{1}$ & $a$ & $\begin{array}{c}\text { Estimated } \\
\text { uncertainty }\end{array}$ \\
\hline \multirow{8}{*}{10} & ${ }^{\circ} \mathrm{C}$ & & $(\AA)$ & \\
\hline & 10 & 5.496 & 3.1 & 0.001 \\
\hline & 15 & 5.390 & 3.1 & .001 \\
\hline & 20 & 5.288 & 3.1 & .001 \\
\hline & 25 & 5.190 & 3.2 & .001 \\
\hline & 30 & 5.095 & 3.2 & .001 \\
\hline & 35 & 5.002 & 3.3 & .001 \\
\hline & & 4.911 & 3.3 & .001 \\
\hline \multirow[t]{7}{*}{20} & 10 & 5.372 & 2.8 & .001 \\
\hline & 15 & 5.260 & 2.9 & .001 \\
\hline & 20 & 5.152 & 2.9 & .001 \\
\hline & 25 & 5.048 & 2.9 & .001 \\
\hline & 30 & 4.949 & 3.0 & .001 \\
\hline & 35 & 4.851 & 3.0 & .001 \\
\hline & 40 & 4.756 & 3.1 & .001 \\
\hline 33.4 & 25 & 4.854 & 3.0 & .001 \\
\hline \multirow[t]{7}{*}{50} & 10 & 4.916 & 2.1 & .003 \\
\hline & 15 & 4.798 & 2.0 & .003 \\
\hline & 20 & 4.690 & 2.1 & .003 \\
\hline & 25 & 4.583 & 2.1 & .003 \\
\hline & 30 & 4.481 & 2.1 & .003 \\
\hline & 35 & 4.384 & 2.1 & .003 \\
\hline & 40 & 4.291 & 2.1 & .003 \\
\hline 70 & 25 & 4.293 & 0 & .005 \\
\hline
\end{tabular}


TABLE 4. Values of the constants for the temperature variation of the dissociation constant

\begin{tabular}{c|c|c|c}
\hline \hline Wt \% Methanol & $A$ & \multicolumn{1}{c|}{$B$} & \multicolumn{1}{c}{$C$} \\
\hline 10 & 1534.587 & 0.6891 & -0.00216628 \\
20 & 1890.389 & -1.5377 & .000824178 \\
50 & 2353.773 & -5.0240 & .00574370 \\
\hline
\end{tabular}

change in heat capacity, which has a large positive value in the aqueous solvent, decreases sharply, reaching a value of $-66 \mathrm{~J} \mathrm{~K}^{-1} \mathrm{~mol}^{-1}$ when half of the mass of the water solvent has been replaced by methanol.

The contrary variation of $\Delta S^{\circ}$ and $\Delta C_{p}^{\circ}$ as the molecular structure of the acid is modified progressively by substitution or as the composition of the solvent is progressively altered has long been observed but is not completely understood. Electrostatic interactions between simple ions and dipolar solvent molecules would be expected to alter the entropy and heat capacity of the system in the same direction. Indeed, orientation of solvent molecules in the neighborhood of the ions should lead to a decrease in both quantities. The fact that methanol is less polar than water is therefore consistent with the observation that $\Delta S^{\circ}$ for the dissociation of diprotonated piperazinium ion increases as methanol is added to the solvent.
Everett and his coworkers [10-12] have suggested that the variation of heat capacity effects in the opposite sense to entropy effects may be caused by "hydrophobic interactions" between neutral molecules and the solvent structure. Although the locus of charge on the monoprotonated piperazinium ion presumably is surrounded by a hydration shell, there remains a considerable length of hydrocarbon chain beyond the influence of the charge. This portion of the structure can interact with the solvent in the same way as a neutral molecule [11]. In the diprotonated ion, however, the two charges at opposite ends of the ring assure, through their cooperative influence, that hydrophobic interactions with the solvent are of little importance.

Solvent effects on the $p K$ of weak acids in methanolwater solvents are strongly dependent on the charge type of the dissociation process [6]. In figure 1, the change in $p K$, namely $p\left({ }_{s} K\right)-p\left({ }_{w} K\right)$, as methanol is added to the aqueous solvent is plotted for acids of four charge types. These acids are dihydrogen phosphate ion [13, 14], acetic acid [15], ammonium ion [5], and the doubly charged piperazinium cation, $\mathrm{PzH}_{2}^{++}$. Although some individual variations are to be expected, the strong interactions between bivalent ions and the solvent molecules are reflected in the sign and magnitude of the solvent effect.

TABLE 5. Standard thermodynamic quantities for the acidic dissociation of $\mathrm{PzH}_{2}^{++}$ion in water-methanol solvent mixtures

\begin{tabular}{|c|c|c|c|c|}
\hline $\begin{array}{c}\text { Wt \% } \\
\text { Methanol }\end{array}$ & $t$ & $\Delta H^{\circ}$ & $\Delta S^{\circ}$ & $\Delta C_{p}^{\circ}$ \\
\hline 10 & $\begin{array}{l}{ }^{\circ} \mathrm{C} \\
10 \\
25 \\
40\end{array}$ & \begin{tabular}{l}
\multicolumn{2}{c}{$\mathrm{mol}^{-1^{\alpha}}$} \\
32,706 \\
$33,068 \quad(69)$ \\
33,448
\end{tabular} & $\begin{array}{l}J \mathrm{~K}^{-1} \mathrm{~mol}^{-1 \alpha} \\
10.3 \\
11.5 \quad(0.2) \\
12.8\end{array}$ & $\begin{array}{c}J K^{-1} \mathrm{~mol}^{-1}{ }^{\alpha} \\
23 \\
25 \quad(16) \\
26\end{array}$ \\
\hline 20 & $\begin{array}{l}10 \\
25 \\
40\end{array}$ & $\begin{array}{ll}34,928 & \\
34,790 & (118) \\
34,645 & \end{array}$ & $\begin{array}{l}20.5 \\
20.0 \quad(0.4) \\
19.6\end{array}$ & $\begin{array}{l}-9 \\
-9 \\
-10\end{array}$ \\
\hline 50 & $\begin{array}{l}10 \\
25 \\
40\end{array}$ & $\begin{array}{l}36,248 \\
35,289 \\
34,281\end{array}$ & $\begin{array}{ll}33.9 & \\
30.6 & (0.3) \\
27.3 & \end{array}$ & $\begin{array}{l}-62 \\
-66 \\
-69\end{array}$ \\
\hline
\end{tabular}

${ }^{\alpha} 4.184 \mathrm{~J}=1 \mathrm{cal}$.

TABLE 6. Solvent effect on the thermodynamic quantities for the acidic dissociation of $\mathrm{PzH}_{2}^{++}$ion in watermethanol solvents at $25^{\circ} \mathrm{C}$

\begin{tabular}{|c|c|c|c|c|}
\hline $\begin{array}{c}\text { Wt \% } \\
\text { Methanol }\end{array}$ & $p K$ & $\Delta H^{\circ}$ & $\Delta S^{\circ}$ & $\Delta C_{p}^{\circ}$ \\
\hline $\begin{array}{l}{ }^{\alpha} 0 \\
10 \\
20 \\
33.4\end{array}$ & $\begin{array}{l}5.333 \\
5.190 \\
5.048 \\
4.854\end{array}$ & $\begin{array}{c}J \mathrm{~mol}^{-1} \\
31,080 \\
33,068 \\
34,790\end{array}$ & $\begin{array}{c}J K^{-1} \mathrm{~mol}^{-1} \\
2.2 \\
11.5 \\
20.0\end{array}$ & $\begin{array}{c}J K^{-1} \mathrm{~mol}^{-1} \\
86 \\
25 \\
-9\end{array}$ \\
\hline $\begin{array}{l}50 \\
70\end{array}$ & $\begin{array}{l}4.583 \\
4.293\end{array}$ & $\begin{array}{l}35.289 \\
\ldots \ldots \ldots \ldots\end{array}$ & 30.6 & -66 \\
\hline
\end{tabular}

${ }^{\alpha}$ Reference [7]. 


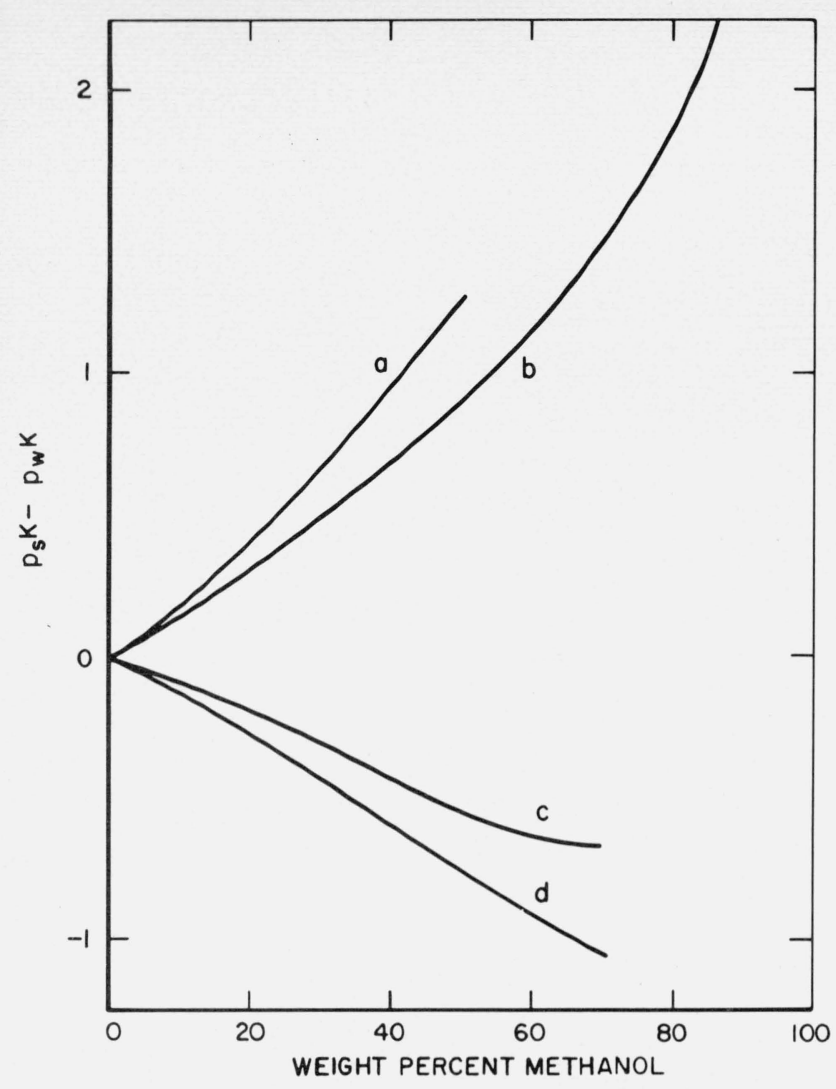

FIGURE 1. Change of $\mathrm{pK}$ with solvent composition for weak acids of four different charge types: (a) dihydrogen phosphate ion; (b) acetic acid; (c) ammonium ion; (d) diprotonated piperazinium ion.

\section{References}

[1] Harned, H. S., and Thomas, H. C., J. Am. Chem. Soc. 57 1666 (1935); 58, 761 (1936). The ${ }_{s} E^{\circ}$ values of Harned and Thomas at $25{ }^{\circ} \mathrm{C}$ have been recalculated (see ref. [4]). The ${ }_{s} E^{\circ}$ values at other temperatures have been corrected in the same ratio.

[2] Bates, R. G., and Rosenthal, D., J. Phys. Chem. 67, 1088 (1963).

[3] Paabo, M., Robinson, R. A., and Bates, R. G., J. Chem. Eng. Data 9, 374 (1964).

[4] Paabo, M., Bates, R. G., and Robinson, R. A., Anal. Chem. 37, 462 (1965).

[5] Paabo, M., Bates, R. G., and Robinson, R. A., J. Phys. Chem. 70, 247 (1966).

[6] Bates, R. G., and Robinson, R. A., Acid-base behavior in methanol-water solutions, in Chemical Physics of Ionic Solutions, B. E. Conway and R. G. Barradas, eds. (John Wiley \& Sons, Inc., New York, N.Y., 1966).

[7] Hetzer, H. B., Robinson, R. A., and Bates, R. G., J. Phys. Chem. 72, 2081 (1968).

[8] Gary, R., Bates, R. G., and Robinson, R. A., J. Phys. Chem 68, 1186 (1964).

[9] Harned, H. S., and Robinson, R. A., Trans. Faraday Soc. 36, $973(1940)$.

[10] Everett, D. H., Landsman, D. A., and Pinsent, B. R. W., Proc. Roy. Soc. A215, 403 (1952).

[11] Cox, M. C., Everett, D. H., Landsman, D. A., and Munn, R. J., J. Chem. Soc. (B), 1373 (1968).

[12] Timimi, B. A., and Everett, D. H., ibid., 1380 (1968).

[13] Ender, F., Teltschik, W., and Schafer, K., Z. Elektrochem. 61, 775 (1957).

[14] Paabo, M., Robinson, R. A., and Bates, R. G., J. Am. Chem. Soc. 87, 415 (1965).

[15] Shedlovsky, T., and Kay, R. L., J. Phys. Chem. 60, 151 (1956).

(Paper 74A5-631) 